\author{
RENATA BABIŃSKA-GÓRECKA \\ ORCID: 0000-0002-9893-3276 \\ Uniwersytet Wrocławski
}

\title{
RYZYKO SOCJALNE W UBEZPIECZENIU EMERYTALNYM. MIĘDZYNARODOWE I KRAJOWE UWARUNKOWANIA PRAWNE I DOKTRYNALNE
}

\begin{abstract}
Abstrakt: Artykuł, opierając się na utrwalonym poglądzie polskiej doktryny, że ziszczenie się ryzyka socjalnego jest przesłanką udzielenia świadczeń z ubezpieczeń społecznych, podaje w wątpliwość słuszność tej tezy w odniesieniu do emerytury. Ponadto stawia pytanie — zważywszy na nowe okoliczności, wobec których stają ludzie w trakcie swojego życia w rezultacie zmian społeczno-gospodarczych towarzyszących transformacji w kierunku społeczeństwa postindustrialnego - czy przesłanką udzielenia ochrony w przypadku prawa do emerytury może być ryzyko socjalne. Dalsze rozważania koncentrują się między innymi na kwestii, jak należałoby rozumieć ewentualne „ryzyko emerytalne (starości)" jako ryzyko socjalne.
\end{abstract}

Słowa kluczowe: ryzyko socjalne, emerytura, prawo zabezpieczenia społecznego, ubezpieczenia społeczne, wiek emerytalny

\section{WPROWADZENIE}

W polskim piśmiennictwie uznaje się niemal zgodnie, że ziszczenie się ryzyka socjalnego jest przesłanką udzielenia świadczeń z ubezpieczeń społecznych ${ }^{1}$. Przy czym poszczególni autorzy, posługując się tym terminem, opisują zwłaszcza i porządkują zastany stan regulacji prawnej w zakresie zabezpieczenia społecznego czy ubezpieczeń społecznych.

Pojawia się jednak pytanie, czy rzeczywiście — zważywszy na nowe okoliczności, w obliczu których stają ludzie w trakcie swojego życia w rezultacie zmian społeczno-gospodarczych towarzyszących transformacji w kierunku spo-

1 Zob. J. Jończyk, Prawo zabezpieczenia społecznego, Warszawa-Kraków 2006, s. 202-203; I. Jędrasik-Jankowska, Pojęcia i konstrukcje prawne ubezpieczenia społecznego, Warszawa 2014, s. 318; T. Szumlicz, Modele polityki społecznej. Monografie i Opracowania, Warszawa 1994, s. 62; G. Uścińska, Ryzyko jako przesłanka ochrony w systemie zabezpieczenia społecznego, „Polityka Społeczna" 2013, nr 11-12, s. 3; K. Ślebzak, Prawo do zabezpieczenia społecznego w Konstytucji RP. Zagadnienia podstawowe, Warszawa 2015, s. 63. 
łeczeństwa postindustrialnego (na przykład masowe zatrudnienie kobiet i wiążąca się z tym modyfikacja struktury zatrudnienia oraz konieczność zapewnienia odmiennego regulowania warunków pracy i zabezpieczenia społecznego w okresach jej nieświadczenia, zatomizowane zawody, nowe formy aktywności zarobkowej) — przesłanką udzielenia ochrony w przypadku prawa do emerytury może być/jest jeszcze ryzyko socjalne. Nieustaloną kwestią pozostaje także to, jak należałoby rozumieć ewentualne „ryzyko emerytalne (starości)” jako ryzyko socjalne.

Nie jest zatem oczywiste, czy przesłanką ukształtowania uprawnień do emerytury w ramach ubezpieczeń społecznych jest ryzyko socjalne. Źródłem wątpliwości $\mathrm{w}$ tym zakresie jest nie tylko regulacja prawa do emerytury $\mathrm{w}$ prawie polskim i związana $\mathrm{z}$ jego stosowaniem refleksja na temat sytuacji społeczno-zawodowej emerytów, poglądy doktryny, lecz także postrzeganie istoty prawa do emerytury, jej funkcji przez samych ubezpieczonych czy świadczeniobiorców. O ile w wypadku zasiłku chorobowego, zasiłku macierzyńskiego czy renty z tytułu niezdolności do pracy panuje powszechna świadomość oraz zgodność co do tego, że dostęp do tych świadczeń otwiera wystąpienie sytuacji utrudniającej lub uniemożliwiającej dalsze zarobkowanie, o tyle prawo do emerytury wiąże się z konkretnym momentem - osiągnięciem określonego w przepisach wieku. Sprawia to, że emerytura w odbiorze społecznym traktowana jest jako swoista zapłata za lata pracy lub lata opłacania składek. Niewątpliwie takie postrzeganie funkcji emerytury jest pochodną regulacji prawnej, zwłaszcza przepisów określających warunki jej nabycia oraz realizacji, ale nie tylko. Znaczenie mają tutaj także inne regulacje prawne, które dają łącznie podstawę do kwestionowania poglądu, że treścią ryzyka socjalnego w ubezpieczeniu emerytalnym jest strata spowodowana ograniczeniem lub wyłączeniem zdolności do pracy (na przykład wypłata gwarantowana lub podział składek na subkoncie). Strata jest postrzegana indywidualnie i odnoszona do danej jednostki, która przez znaczną część swego życia własną pracą zapewniała sobie środki do życia.

Jednocześnie przedstawiciele polskiej doktryny przedstawiają kilka stanowisk odnośnie do kwestii ujmowania i rozumienia zasadniczej przesłanki ukształtowania prawa do emerytury. Jak już wspomniano, zasadniczo stwierdza się, że przesłanką tą jest jednak ziszczenie się ryzyka socjalnego. Wskazuje się jednocześnie, że może ono przybierać różną treść. Wymienia się zatem ryzyko starości, ryzyko domniemanej niezdolności do pracy z powodu wieku, ryzyko długotrwałego zatrudnienia, ryzyko długotrwałego zatrudnienia pozwalającego na zejście $\mathrm{z}$ rynku pracy oraz ryzyko dożycia określonego wieku ${ }^{2}$. Wstępnie warto jedynie zasygnalizować, że nie każda wymieniona tu koncepcja „ryzyka emerytalnego” (,ryzyka starości”) pozostaje ryzykiem socjalnym.

2 Zob. D.E. Lach, Adekwatność systemu emerytalnego a ryzyko emerytalne - przyczynek do dyskusji, „Ubezpieczenia Społeczne. Teoria i praktyka” 2018, nr 1, s. 102 n. 


\section{RYZYKO DOMNIEMANEJ NIEZDOLNOŚCI DO PRACY Z POWODU WIEKU}

Wedle najpowszechniejszej, choć obecnie coraz częściej kwestionowanej w doktrynie koncepcji (powody kwestionowania różnią się jednak zasadniczo), ryzyko w ubezpieczeniu emerytalnym wiąże się z konwencjonalną (domniemaną) niezdolnością do pracy. Koncepcja ta zarazem postrzega wiek warunkujący nabycie prawa do emerytury jako pewną składową samej konstrukcji ryzyka. Uznaje się bowiem, że „ryzyko osiągnięcia wieku emerytalnego jest ryzykiem człowieka zatrudnionego i polega na niebezpieczeństwie utraty zatrudnienia w związku $z$ dożyciem wieku emerytalnego jako domniemanego wieku niezdolności do pracy (służby)"’3.

$\mathrm{Z}$ takim postrzeganiem ryzyka, łączącym jednocześnie kategorię wieku emerytalnego $\mathrm{z}$ domniemaną niezdolnością do pracy, mamy do czynienia $\mathrm{w}$ przepisach ratyfikowanej przez Polskę konwencji nr 102 MOP z 28 czerwca 1952 roku o minimalnych normach zabezpieczenia społecznego. Zgodnie z jej przepisem art. 26 ust. 2 wyższy wiek może być ustalony ze względu na zdolność do pracy osób starszych w danym kraju. Inaczej do tego zagadnienia podchodzi nieratyfikowana przez Polskę konwencja MOP nr 128 z 7 czerwca 1967 roku dotycząca świadczeń w razie inwalidztwa, na starość i w razie śmierci żywiciela rodziny, wedle której przedmiotem ochrony jest także przypadek przeżycia ponad ustalony wiek, który nie powinien przekraczać 65 lat. Niemniej jednak wyższy wiek może być ustalony przez właściwe władze ze względu na odpowiednie kryteria demograficzne, ekonomiczne i społeczne, uzasadnione statystykami (art. 15). Wyraźnie zatem tylko w przepisach konwencji nr 102 wiąże się sytuację przeżycia ponad wiek 65 lat z kwestią domniemanej zdolności (niezdolności) do pracy. Wykładnia kontekstowa przepisu art. 26 konwencji nr 102 nie pozostawia wątpliwości, że użyte w jej ust. 2 sformułowanie „wyższy wiek może być ustalony ze względu na zdolność do pracy osób starszych w danym kraju" dookreśla także jej ust. 1 oraz 2 ab initio, to jest wskazuje na istotę wieku emerytalnego ustalonego w tym przepisie na poziomie 65 lat. Podobnie w zaleceniu MOP nr 67 wskazano, że zabezpieczenie dochodu powinno odbywać się ,przez zwracanie (do odpowiedniej wysokości) dochodów utraconych z powodu niezdolności do pracy (włączając podeszły wiek)".

Koncepcja ujmowania wieku emerytalnego jako wieku domniemanej niezdolności do pracy, a tym samym wiążąca $\mathrm{z}$ jego osiągnięciem także ziszczenie się ryzyka socjalnego, to jest domniemanej niezdolności do pracy, jest obecnie

3 J. Jończyk, ZUS jako instytucja ubezpieczeń społecznych, [w:] Problemy ubezpieczeń społecznych. W 70-lecie istnienia Zakładu Ubezpieczeń Społecznych, red. U. Jackowiak, A. Malaka, Wrocław 2004, s. 9; podobnie też W. Muszalski, Ubezpieczenie społeczne, Warszawa 2004, s. $173-$ 174; B. Wagner, Wiek emerytalny jako zdarzenie prawa pracy, „Praca i Zabezpieczenie Społeczne” 2001, nr 3, s. 20-21. 
zawodna z kilku powodów. Nie są to powody jednorodne. Jedne są rezultatem decyzji ustawodawcy, do pewnego stopnia determinowanej czynnikami związanymi $\mathrm{z}$ prowadzeniem polityki społecznej $\mathrm{w}$ warunkach globalizacji, inne zaś następstwem zmian (okoliczności faktycznych) wynikających z przejścia ze społeczeństwa industrialnego do społeczeństwa postindustrialnego.

W pierwszej grupie powodów możemy wyróżnić przepisy określające współczesną wspólnotę osób podlegających ubezpieczeniu emerytalnemu. Wspólnota ta jest bowiem różnorodna, niehomogeniczna. W przeciwieństwie do dawnej industrialnej wspólnoty ryzyka — branżowej i zawodowej — współczesną wspólnotę tworzą zarówno osoby pracujące, jak i osoby nieaktywne zarobkowo i zawodowo, na przykład rodzice opiekujący się dziećmi czy osoby sprawujące opiekę nad niesamodzielnymi członkami rodziny. Mogą do niej należeć — na zasadzie dobrowolności - wszystkie inne osoby, które przejawiają wolę ubezpieczenia się i zdolność finansową do opłacenia składki, a nie mają tytułu do obowiązkowego ubezpieczenia. Takie ukształtowanie zakresu podmiotowego ubezpieczenia emerytalnego (i rentowego) budzi zastrzeżenia ${ }^{4}$. Choć uznaje się, że rozwiązanie to ma na celu na przykład dowartościowanie pracy nieprodukcyjnej związanej z pełnieniem społecznie ważnych ról — rodziców czy opiekunów, to jednak podważa ono nie tylko założenie o jednorodnej, solidarnej wspólnocie ryzyka, lecz także godzi w ekonomiczne i społeczne fundamenty zabezpieczenia społecznego. W tych przypadkach źródłem „,finansowania” składki są często środki publiczne, ponadto podstawa wymiaru składki jest niska, oscylując w okolicach minimalnego wynagrodzenia za pracę, co przy repartycyjnej metodzie finansowania zabezpieczenia emerytalnego ma istotne negatywne konsekwencje.

Tymczasem prowadzone badania dowodzą, po pierwsze, że kluczowymi czynnikami stabilności systemów zabezpieczenia społecznego są wskaźnik zatrudnienia i współczynnik aktywności zawodowej ${ }^{5}$. Po drugie, promowana przez ustawodawcę dezaktywizacja rodziców małych dzieci czy też opiekunów osób niesamodzielnych jest niekorzystna zarówno dla samego systemu, jak i tych właśnie osób. Rozwiązania te - mając negatywny wpływ w szczególności na aktywność zawodową kobiet - sprzyjają uzyskiwaniu przez nie niskich dochodów oraz ubóstwu na starość. Można by zatem postulować zmianę tych rozwiązań i rezygnację z tak szerokiego zakresu niezarobkowych/niezawodowych tytułów do objęcia ubezpieczeniem emerytalnym. Tym bardziej że emerytury, które można uzyskać z tytułu wychowywania dzieci lub opieki nad niesamodzielnymi członkami rodziny, będą — z uwagi na niskie składki obliczane zasadniczo od kwot rów-

${ }^{4}$ Zob. F. Brosius-Gersdorf, Kompensowanie w systemach emerytalnych okresów poza zatrudnieniem poświęconych opiece nad dziećmi i chorymi członkami rodziny, „Ubezpieczenia Społeczne. Teoria i praktyka" 2018, nr 1, s. 2 n.

5 H.H. Konkolewsky, Demografia, mobilność i migracje w Europie oraz wptyw tych zjawisk na stabilność systemów zabezpieczenia spotecznego, [w:] Wyzwania XXI wieku a systemy emerytalne, red. A. Kostrowiecka, M. Marczyk, Warszawa-Gdańsk 2015, s. 13. 
nych lub zbliżonych do minimalnego wynagrodzenia za pracę - świadczeniami o niskiej stopie zastąpienia, niechroniącymi przed ubóstwem ${ }^{6}$.

O ile powody należące do pierwszej grupy można zasadniczo usunąć, zmieniając odpowiednio prawo, o tyle powody z drugiej grupy mają inny charakter. Należą do nich uwarunkowania związane $\mathrm{z}$ funkcjonowaniem społeczeństwa postindustrialnego, to jest: rozwinięcie sektora usług przy jednoczesnym spadku znaczenia przemysłu, masowe zatrudnienie kobiet, uzależnienie wysokości świadczeń emerytalnych — szerzej faktycznych ekonomicznych możliwości prowadzenia polityki społecznej — od czynników makroekonomicznych, przerwy w aktywności zarobkowej będące skutkiem odziaływania realiów społecznych i rynku pracy, przejściowa praca w niepełnym wymiarze, częste zmiany kwalifikacji i poszukiwania nowej pracy. W sumie prowadzi to do indywidualizacji strategii emerytalnej7. Dlatego też żadna zmiana przepisów prawnych nie może zagwarantować jednorodnej z perspektywy utraty sił do pracy (zdolności do pracy) wspólnoty ubezpieczonych. Otóż także w grupie osób zarobkujących zawodowo w tej kwestii obserwuje się daleko idące zróżnicowanie. Są zawody, które pozwalają ludziom pozostawać aktywnymi w danej dziedzinie niemal do śmierci ${ }^{8}$, są zaś takie, w wypadku których biologiczna starość wiąże się z utratą lub znacznym ograniczeniem zdolności do pracy. Dlatego też nie sposób zdefiniować wspólną dla wszystkich granicę domniemanej niezdolności do pracy9

\section{TAK ZWANE RYZYKO DŁUGOTRWAŁEJ PRACY (STAŻ). PRAWO DO EMERYTURY Z TYTUŁU WYSŁUGI}

W wyroku Trybunału Konstytucyjnego z dnia 7 maja 2014 roku (K 43/12, ZU 2014, nr 5A, poz. 50, pkt C.III.3.4) posłużono się hybrydową konstrukcją ryzyka emerytalnego, podkreślając, że „ustawodawca musi zatem uwzględnić zdolność jednostki do pracy zarobkowej w typowych sytuacjach oraz — co ważne — kierować się dyrektywą, by odbiór wysługi czy zasługi związanej z pracą był w sytuacjach typowych możliwy".

Ostatnie sformułowanie zawarte w cytowanym uzasadnieniu wyroku Trybunału Konstytucyjnego daje asumpt do analizowania prawa do emerytury z tytułu wysługi, czyli ewentualnie tak zwanego ryzyka długotrwałej pracy.

Prawo do emerytury z tytułu wysługi może być analizowane na kilku płaszczyznach. Jedną z nich jest płaszczyzna terminologiczna i związana z nią -

6 Por. F. Brosius-Gersdorf, op. cit., s. 11.

7 D. Dzienisiuk, Prawo pracy a prawo ubezpieczeń społecznych, Warszawa 2016, s. 242.

${ }^{8}$ K. Hagemajer, Adekwatność zreformowanych systemów emerytalnych, „Ubezpieczenia Społeczne. Teoria i praktyka” 2018, nr 1, s. 34.

9 D.E. Lach, O zabezpieczeniu na starość i ryzyku „starości” — raz jeszcze, „Praca i Zabezpieczenie Społeczne” 2014, nr 3, s. 6. 
w polskich warunkach — wykładnia historyczna. Inną — płaszczyzna teoretyczna odnosząca się do znaczenia ryzyka socjalnego oraz pozostałych konstrukcji związanych ze zdarzeniem losowym, występujących w polskiej doktrynie prawa zabezpieczenia społecznego.

W polskim piśmiennictwie podkreśla się zatem, że od 1968 roku nastąpiła istotna zmiana $\mathrm{w}$ zakresie regulacji prawnej ubezpieczenia emerytalnego, dotycząca między innymi ustawowej terminologii. Otóż dotychczasowe określenie „renta starcza” zastąpiono zwrotem „emerytura”. Jak podkreśla się w doktrynie, określenie „emerytura”, pochodzące od łacińskiego emeritus, uzależnia ochronę od wysługi lub zasługi ${ }^{10}$. Podnosi się, że chodzi tu zatem o ryzyko emerytalne, a nie starości. Pojęcie „ryzyko wieku emerytalnego” kojarzy się zatem bardziej z wysługą, zasługą niż z procesami biologicznym ${ }^{\mathrm{i} 11}$.

Taki tok rozumowania nie znajduje jednak potwierdzenia w szczegółowej regulacji prawnej.

Po pierwsze, od 1954 do 1991 roku, czyli już po wspomnianej zmianie terminologicznej, prawo do emerytury było zawieszane na czas osiągania zarobku $\mathrm{z}$ zatrudnienia lub dochodu $\mathrm{z}$ innych źródeł. Rolą emerytury było nie zasłużone korzystanie z owoców swojej pracy, lecz zabezpieczenie dochodu wobec utraty sił do pracy połączonej z zaprzestaniem jej wykonywania. Dopiero zmiana realiów społeczno-gospodarczych spowodowała, że od 1991 roku łączenie pobierania pełnej emerytury z dalszą aktywnością zarobkową zależało od wysokości uzyskiwanego przychodu.

Po drugie, prawo do emerytury mogą nabyć osoby nigdy nieaktywne zawodowo i zarobkowo, które jednak z różnych względów podlegają ubezpieczeniu emerytalnemu. W ich przypadku zatem nie można wyróżnić elementu wysługi. Powodem objęcia ich ochroną ubezpieczeniową jest natomiast dążenie do odciążenia w przyszłości funduszy pomocy społecznej i przerzucenia ciężaru finansowania świadczeń ze wspólnoty narodowej na fundusz ubezpieczeń społecznych.

Argumentem na rzecz stanowiska, że w wypadku prawa do emerytury mamy do czynienia z ryzykiem długotrwałej pracy, mogłoby być ewentualnie twierdzenie, że obecnie - w wyniku reform - wysokość świadczeń emerytalnych jest ściśle powiązana z wysokością zarobków i składek płaconych w okresie całej aktywności zawodowej. Oznaczałoby to, że emeryt sam sobie wypracował to świadczenie swoją długotrwałą pracą. Należy jednak zauważyć, że także w przypadku emerytury $\mathrm{w}$ formule zdefiniowanej składki mamy elementy redystrybucyjne (solidarnościowe). Należy do nich wspomniany już — dotyczący niektórych grup ubezpieczonych — brak aktywności zawodowej i zarobkowej, połączony jednak

${ }^{10}$ K. Ślebzak, Prawo do zabezpieczenia społecznego w Konstytucji RP. Zagadnienia podstawowe, Warszawa 2015, s. 124.

11 B. Wagner, Przestanki prawa do emerytury w starym i nowym systemie, [w:] Ryzyko starości — problemy zabezpieczenia, red. U. Jackowiak, L. Abramowicz, Kraków 2007, s. 21; K. Antonów, Prawo do emerytury, Warszawa 2004, s. 35. 
z ewidencjonowaniem składek pochodzących ze źródeł publicznych itp. Z tego też powodu nie można ujmować ryzyka socjalnego w aktualnym ubezpieczeniu emerytalnym jako ryzyka długotrwałej pracy, emerytury zaś jako świadczenia z tytułu wysługi - lat pracy.

Tym samym w powszechnym systemie ubezpieczeń społecznych brakuje w odniesieniu do wszystkich tytułów przesłanek dla wysługi, nawet tylko w postaci pracy społecznie użytecznej. Należy także dodać, że w nowszych opracowaniach zwraca się uwagę na to, że terminologia emerytalna została przejęta do ubezpieczenia emerytalnego z dawnego prawa urzędniczego i współcześnie miałaby sens jedynie w ściśle rozumianym zatrudnieniu służbowym, dlatego nie warto się trzymać tej niejednoznacznej tradycji. Wszak dodaje się, że termin emeritus może oznaczać „zasłużony”, ale także „wysłużony, zużyty, niezdolny do użycia”12.

Po trzecie, formuła wymiaru emerytury (zdefiniowanej składki) nie zawiera elementów kompensujących uzyskiwanie relatywnie niskich zarobków (przychodów) pomimo wykonywania prac wysoce społecznie użytecznych. Osoby wykonujące prace wysoce społecznie użyteczne uzyskują niejednokrotnie wynagrodzenie poniżej przeciętnego, co sprawia, że przy zastosowaniu formuły wymiaru emerytury określanej jako formuła zdefiniowanej składki uzyskają emeryturę zastępującą utracony zarobek na poziomie poniżej 40\%. Postępujące rozwarstwienie zarobkowe, związana z nim nierówność wkładu i udziału oraz obowiązku i uprawnienia sprawiają, że nie można dzisiaj prawa do emerytury (przyszłej emerytury) uzasadniać w każdym przypadku wysługą/zasługą.

Wreszcie przeciwko takiemu postrzeganiu ryzyka socjalnego w ubezpieczeniu emerytalnym przemawiają także argumenty natury teoretycznej. Zasadne jest rozumienie ryzyka socjalnego jako prawdopodobieństwa wystąpienia niebezpieczeństwa wywołującego, w określonych warunkach i okolicznościach (prawnych, społecznych i ekonomicznych), negatywne skutki socjalno-bytowe dla jednost$\mathrm{ki}^{13}$. Przy czym niebezpieczeństwo starości, choroby itp. jest jednym z elementów teorii ryzyka socjalnego. Do wyznaczników tego pojęcia należą zatem biologiczne lub społeczne ograniczenia albo wyłączenia podejmowania aktywności zarobkowej, do których zalicza się między innymi utratę sił związaną z wiekiem. Wpływ tych zdarzeń (niebezpieczeństw) na zdolność do zarobkowania mówi o prawdopodobieństwie wystąpieniu ryzyka socjalnego. Charakteryzujące ryzyko socjalne

12 J. Jończyk, O ubezpieczeniu społecznym (wyktad), „Praca i Zabezpieczenie Społeczne” 2017, nr 9, s. 10.

13 Nie jest natomiast zasadne określanie ryzyka socjalnego bezpośrednio mianem niebezpieczeństwa wystąpienia zdarzenia - zob. J. Jończyk, Prawo..., s. 13. Jak pisze T. Michalski, ujmowanie ryzyka jako niebezpieczeństwa jest jednym z przykładów potocznego podejścia do tej kategorii i ma niewielką wartość teoretyczną — idem, Ryzyko w działalności człowieka, [w:] Podstawy ubezpieczenia, t. 1. Mechanizm i funkcje, red. J. Monkiewicz, Warszawa 2000, s. 31. Por. też G. Uścińska, Europejskie standardy zabezpieczenia społecznego a współczesne rozwiązania polskie, Warszawa 2005, s. 62; eadem, Ryzyko jako przestanka..., s. 7, przyp. 2. 
niebezpieczeństwo jest stałe, niezmienne i wpisane w etapy życia człowieka. Innymi elementami o cechach sprawczych (decydują o powstaniu straty) oraz zmiennych są generalne warunki i okoliczności charakterystyczne dla danego etapu rozwoju cywilizacyjnego (praca, rynek, rodzina) oraz okoliczności indywidualne, jednostkowe (wykonywanie pracy zarobkowej, brak pracy, niepełnosprawność, obciążenia rodzinne itp.).

Tymczasem pogląd, jakoby w ubezpieczeniu emerytalnym przesłanką ochrony było ryzyko długotrwałej pracy, w istocie utożsamia to ryzyko z - wyróżnionym w polskiej doktrynie przez I. Jędrasik-Jankowską — zdarzeniem prawnym (ryzykiem ubezpieczeniowym). Przy czym nie ulega wątpliwości, że ryzyko socjalne oraz wyróżnione przez I. Jędrasik-Jankowską ryzyko (zdarzenie) ubezpieczeniowe są różnymi kategoriami ${ }^{14}$. Ryzyko socjalne postrzegane jako pewien stan faktyczny stan rzeczy, może być przesłanką kształtowania systemu zabezpieczenia społecznego, konstrukcja zaś ryzyka (zdarzenia) ubezpieczeniowego jest tworem prawnym, o którego istnieniu przesądza ustawodawca, uznając, że skutki danego zdarzenia losowego jako zjawiska przyrody wymagają objęcia ochroną w postaci określonego świadczenia. Chodzi tu o zdarzenia losowe, które mogą bezpośrednio zagrozić zdolności do pracy ${ }^{15}$.

Ryzyko socjalne oraz ryzyko ubezpieczeniowe są więc odrębnymi kategoriami, które rozpatrujemy na różnych płaszczyznach. Ryzyko (socjalne, społeczne) jest stanem realnej rzeczywistości, ma charakter historyczny i zawsze istnieje w jakimś kontekście kulturowym, społecznym i ekonomicznym ${ }^{16}$. Sprawne funkcjonowanie systemu ubezpieczeń społecznych powinno odnosić się do katalogu ryzyk i ubezpieczeniowych zasad organizacji wspólnot ryzyka ${ }^{17}$.

Długotrwała praca (staż) nie może tworzyć zarówno ryzyka socjalnego, jak i ryzyka (zdarzenia) ubezpieczeniowego. W koncepcji ryzyk (zdarzeń) ubezpieczeniowych występuje bowiem element skutków zdarzenia losowego jako zjawiska przyrody. Długotrwała praca nie jest niewątpliwie zdarzeniem losowym, które bezpośrednio może wyłączyć lub ograniczyć zdolność do pracy. Tym bardziej także długotrwała praca nie jest ryzykiem socjalnym. Nie generuje ona straty w postaci utraty środków do życia.

14 I. Jędrasik-Jankowska, Ryzyka ubezpieczeniowe, [w:] Problemy prawne ubezpieczenia społecznego, red. B. Wagner, Kraków 1996, s. 91.

15 Ibidem, s. 92.

16 T. Szumlicz, Świadomość ryzyka społecznego jako podstawa wiedzy o systemie ubezpieczeń społecznych, „Ubezpieczenia Społeczne. Teoria i praktyka” 2017, nr 1, s. 4; J. Michalak, Refleksje nad pojęciem ryzyka, ,Ruch Prawniczy, Ekonomiczny i Socjologiczny” 2004, nr 1, s. 121.

17 T. Szumlicz, Świadomość..., s. 3. 


\section{TAK ZWANE RYZYKO DOŻYCIA OKREŚLONEGO WIEKU - WIEKU EMERYTALNEGO}

Zgodnie z przepisami konwencji MOP nr 128 z 7 czerwca 1967 roku dotyczącej świadczeń w razie inwalidztwa, na starość i w razie śmierci żywiciela rodziny w przypadku świadczeń emerytalnych przedmiotem ochrony jest przypadek przeżycia ponad ustalony wiek (art. 15 ust. 1), który nie powinien przekraczać 65 lat; jednakże wyższy wiek może być ustalony przez właściwe władze ze względu na odpowiednie kryteria demograficzne, ekonomiczne i społeczne uzasadnione statystykami (art. 15 ust. 2 i 3).

Podobnie w przepisie art. 67 ust. 1 Konstytucji RP, wysławiającym prawo do zabezpieczenia społecznego, wyraźnie odróżnia się od niezdolności do pracy sytuację osiągnięcia wieku emerytalnego. Dlatego w doktrynie stwierdza się też, że w odniesieniu do regulacji ustawowej prawa do emerytury mamy do czynienia z ryzykiem dożycia wieku emerytalnego. Jednocześnie zauważa się, że to dożycie wieku emerytalnego jest stanem faktycznym zarówno niepewnym, z czym można się zgodzić, jak i niekorzystnym, co budzi już wątpliwości ${ }^{18}$. Niekorzystność dożycia wieku emerytalnego polega — zdaniem cytowanego autora — na tym, że wiąże się z tym skutek w postaci utraty dochodu z pracy. Oznacza to jednocześnie, że treścią wyróżnionego ryzyka dożycia wieku emerytalnego musi być dodatkowo - poza osiągnięciem danego wieku - także zaprzestanie wykonywania pracy ${ }^{19}$. W przeciwnym razie $-\mathrm{z}$ powodu braku straty — samo dożycie wieku emerytalnego nie może być uznane za ziszczenie się ryzyka socjalnego. Dlatego też uzależnienie nabycia i realizacji prawa do emerytury od samego osiągnięcia określonego wieku - nazwanego nawet wiekiem emerytalnym - oznaczałoby uniezależnienie tego świadczenia od ziszczenia się ryzyka socjalnego.

\section{WIEK EMERYTALNY JAKO WARUNEK A RYZYKO SOCJALNE JAKO PRZESEANKA OCHRONY}

Przyjmując koncepcję jednolitego wieku emerytalnego, wiek ten można ustalić jedynie w taki sposób, by odpowiadał on biologicznemu spadkowi sił do pracy. Typowe dla okresu starzenia się zmiany biologiczne oraz problemy chorobowe $\mathrm{z}$ upływem czasu, różnym $\mathrm{w}$ indywidualnych przypadkach, nieodwracalnie prowadzą do całkowitej niemożności utrzymywania się przez osoby starsze z własnej pracy $^{20}$. Ustalając granicę wieku emerytalnego przez odwołanie się do tych procesów, można zastosować obiektywne kryteria oparte na wymienionych w przepi-

\footnotetext{
18 Zob. K. Antonów, op. cit., s. 41.

19 Ibidem.

20 D. Dzienisiuk, op. cit., s. 241-242.
} 
sach konwencji MOP nr 128 statystykach demograficznych, ekonomicznych i społecznych. Zasadniczą rolę powinna zatem odgrywać definicja pojęcia starości, odwołująca się do jej biologicznych, społecznych i gospodarczych determinant ${ }^{21}$.

Wiek emerytalny nie musi być konstrukcją formułowaną na użytek kategorii ryzyka socjalnego, na jednoznaczne określenie momentu jego ziszczenia się. Przy oddzieleniu obu tych kategorii wiek emerytalny może być tylko punktem orientacyjnym dla ustawodawcy, który uzależni od niego nabycie prawa do emerytury, a także dla tych wszystkich, którzy będą chcieli zachować aktywność zawodową dłużej niż do osiągnięcia jednolitego wieku emerytalnego.

Ponieważ iluzją jest określenie sztywnego wieku emerytalnego jako wieku utraty zdolności do pracy (ziszczenie się ryzyka), celowe jest określenie tej granicy, przede wszystkim uwzględniając ogólne kryteria biologiczne oraz dodatkowo — wynikające ze statystyk — gospodarcze i demograficzne. Choć biologia człowieka nie zmieniła się w ciągu setek lat i starości doświadczają wszyscy w podobnym czasie, to jednak czynniki społeczne i ekonomiczne sprawiają, że większe problemy zdrowotne pojawiają się statystycznie później i jest to — co do zasady - trend stały i rozwojowy ${ }^{22}$.

Wpisanie w ogólną konstrukcję emerytury zarówno kategorii wieku emerytalnego, jak i ryzyka socjalnego wymaga oddzielenia mechanizmów określenia wieku i jego roli w procesie nabywania uprawnień emerytalnych od sposobu określenia momentu ziszczenia się ryzyka socjalnego i jego znaczenia dla nabycia i realizacji prawa do emerytury. Zapewni to zarazem konieczną elastyczność w faktycznym dostępie do emerytury bez potrzeby wprowadzania różnych granic wieku emerytalnego czy też — w razie przyjęcia jednolitej, powszechnej granicy wieku emerytalnego - nadmiernego, bez względu na uwarunkowania biologiczne, statystyki demograficzne i inne, opóźniania lub przyspieszania momentu nabycia i realizacji emerytury, co utrudniałoby stworzenie adekwatnego systemu emerytalnego. Z osiągnięciem wieku emerytalnego nie trzeba zatem wiązać zaprzestania aktywności zawodowej i utraty płynących stąd dochodów. Jednocześnie osiągnięcie wieku emerytalnego nie musi oznaczać pobierania emerytury. Nie sposób bowiem określić właściwy wiek emerytalny — zarówno z perspektywy ekonomicznej (możliwość finasowania zabezpieczenia emerytalnego), jak i z perspektywy ubezpieczonego (adekwatna wysokość emerytury oraz odpowiedni moment jej pobierania - ogólny komfort życia), który byłby zarazem wyznacznikiem ziszczenia się ryzyka socjalnego ${ }^{23}$.

21 K. Hagemajer, op. cit., s. 24.

22 A. Börsch-Supan, Demografia i czas aktywności zawodowej: co to jest „właściwy” wiek emerytalny?, „Ubezpieczenia Społeczne. Teoria i praktyka” 2018, nr 1, s. 50-53.

${ }^{23}$ H. Zalewska, Wybrane zagadnienia i dane statystyczne opisujące problem wieku emerytalnego, „Ubezpieczenia Społeczne. Teoria i praktyka” 2018 nr 1, s. 73. 


\section{PODSUMOWANIE}

W podejściu ekonomicznym do zagadnień wieku emerytalnego, ryzyka socjalnego, wysokości emerytury zwraca się uwagę na adekwatność systemów emerytalnych oraz zapewnienie trwałych możliwości ich finansowania ${ }^{24}$. Są tu wymieniane dwa sposoby: albo przesuwanie granicy wieku w tempie proporcjonalnym do zmiany struktury wiekowej ludności, albo w razie zachowania granicy wieku proporcjonalne obniżenie wysokości emerytury w relacji do wcześniejszych zarobków ${ }^{25}$.

W tym drugim przypadku emerytura nie byłaby adekwatna, co w dłuższym czasie może podważać finansową stabilność i możliwość trwałego finansowania systemu emerytalnego. Z kolei zmiana granicy wieku emerytalnego (jej podnoszenie) $\mathrm{w}$ tempie odpowiadającym wydłużaniu się okresu zdolności do pracy nie wydaje się rozwiązaniem całkowicie dobrym z uwagi na to, że nie można ustalić takiej uniwersalnej granicy dla wszystkich zawodów, sposobów oraz form zarobkowania.

Dlatego też należy odrzucić pozorny wybór, to jest twierdzenie, jakoby w ubezpieczeniach społecznych ustawodawca mógł powiązać szczegółową konstrukcję ryzyka emerytalnego z dożyciem określonego wieku lub z zaprzestaniem aktywności zawodowej i zarobkowejej.

Określenie wieku emerytalnego traktowanego jako składowa konstrukcji ryzyka socjalnego jest jedną z najbardziej drażliwych kwestii, jest wynikiem sprzecznych bodźców i napięć między sytuacją ekonomiczną, polityką zatrudnienia i zabezpieczenia społecznego a prawem pracy ${ }^{27}$.

Dowodzi tego zmieniający się oraz budzący różnego typu wątpliwości, stan regulacji prawa do emerytury zawartej w polskim prawie ubezpieczeń społecznych. W kontekście powiązania wieku emerytalnego z kategorią ryzyka socjalnego należy zwrócić uwagę na przepis art. 103a ustawy emerytalnej. Zgodnie z nim prawo do emerytury ulega zawieszeniu bez względu na wysokość przychodu uzyskiwanego przez emeryta $z$ tytułu zatrudnienia kontynuowanego bez uprzedniego rozwiązania stosunku pracy z pracodawcą, na rzecz którego wykonywał je bezpośrednio przed dniem nabycia prawa do emerytury.

Jednocześnie w orzeczeniu z dnia 13 listopada 2012 roku (K 2/12, ZU 2012, $\mathrm{nr} 10 \mathrm{~A}$, poz. 121) Trybunał Konstytucyjny przedstawił kontrowersyjny pogląd, że przepis art. 103a ustawy emerytalnej określa treść ryzyka emerytalnego. Treścią tego ryzyka jest - w ocenie Trybunału — prawo do zaprzestania pracy po osiągnięciu wieku emerytalnego.

\footnotetext{
24 K. Hagemajer, op. cit., s. 25.

25 Ibidem.

26 D. Dzienisiuk, op. cit., s. 242.

27 Ibidem.
} 
Mając na uwadze przywołane twierdzenie Trybunału, należy dostrzec, że w polskim ustawodawstwie całościowa konstrukcja prawa do emerytury po osiągnięciu wieku emerytalnego wynoszącego 65 lat dla mężczyzn i 60 lat dla kobiet jest uregulowana odmiennie dla ubezpieczonych będących pracownikami oraz dla pozostałych ubezpieczonych, na przykład osób prowadzących działalność gospodarczą. Ogólnie bowiem dla tak zwanych młodszych ubezpieczonych, czyli urodzonych po 31 grudnia 1948 roku, warunkiem nabycia prawa do emerytury jest osiągnięcie tego powszechnego wieku emerytalnego. Jednakże w przypadku ubezpieczonych będących pracownikami w chwili nabycia prawa do emerytury (osiągnięcia wieku emerytalnego) realizacja tego uprawnienia, czyli wypłata emerytury, jest uzależniona od rozwiązania stosunku pracy. W przypadku innych ubezpieczonych wraz z osiągnięciem wieku emerytalnego zarówno nabywa się prawo do emerytury, jak i następuje jej wypłata bez konieczności spełnienia dodatkowych warunków, to jest zaprzestania wykonywania dotychczasowej aktywności zarobkowej. Dodatkowo należy zauważyć, że także pracownik, osiągnąwszy wiek emerytalny, może - po rozwiązaniu stosunku pracy i uzyskaniu wypłaty emerytury — nawiązać ponownie stosunek pracy lub podjąć inną aktywność zarobkową i jednocześnie pobierać emeryturę w pełnej wysokości bez względu na wysokość uzyskiwanego zarobku/dochodu.

Twierdzenie Trybunału Konstytucyjnego jakoby przepis odnoszący się wyłącznie do przesłanek nabycia i realizacji prawa do emerytury przez pracowników wyznaczał treść ryzyka socjalnego, powinno prowadzić do kolejnych wniosków, że, po pierwsze, inna jest treść tego ryzyka w przypadku pracowników, a inna w przypadku pozostałych ubezpieczonych (prawo do zaprzestania pracy po osiągnięciu wieku emerytalnego oraz samo osiągnięcie wieku emerytalnego) oraz, po drugie, że ryzyko to jest różne także dla samych pracowników. Otóż dla tych, którzy rozwiązali stosunek pracy i po odwieszeniu prawa do emerytury powrócili do aktywności zarobkowej, byłoby to de facto tak zwane ryzyko osiągnięcia wieku emerytalnego. Z kolei w przypadku tych, którzy po rozwiązaniu stosunku pracy i uzyskaniu emerytury nie wrócili już do aktywności zarobkowej, ryzyko to oznaczałoby prawo do zaprzestania pracy po osiągnięciu wieku emerytalnego.

Nie ulega wątpliwości, że w systemie powszechnym i opartym na wzajemności nie powinno być miejsca dla różnicowania treści chronionego ryzyka w zależności od okoliczności pozasystemowych. Oznaczałoby to różnicowanie podstawowej cechy konstrukcyjnej wedle cechy nierelewantnej dla systemu powszechnego i w pozostałym zakresie jednolicie ukształtowanego ${ }^{28}$. Dlatego należy uznać, że powodem wprowadzenia do prawa emerytalnego instytucji zawieszenia wypłaty emerytury w przypadku pracowników, którzy po osiągnięciu wieku emerytalnego kontynuują wykonywanie pracy w ramach stosunku pracy, są zatem względy

28 Ibidem, s. 252-253. 
związane z celami polityki zatrudnienia ${ }^{29}$, a nie względy teoretyczne dotyczące istoty i treści ryzyka socjalnego.

Jednocześnie warto rozważyć zastosowanie w pełnym zakresie podmiotowym — a nie tylko wobec pracowników — konstrukcji zawieszenia realizacji emerytury w razie kontynuowania lub podjęcia na nowo aktywności zawodowej po osiągnięciu wieku emerytalnego. Takie rozwiązanie przewidziano w przepisie art. 26 ust. 3 konwencji nr 102 MOP. Nadto szczegółowa analiza polskiego prawa emerytalnego skłania do wniosku, że nie jest merytorycznie uzasadnione, by określenie warunków realizacji prawa do emerytury było zróżnicowane na podstawie kryterium tytułu ubezpieczenia, w szczególności wedle podziału na ubezpieczenie pracownicze z tytułu stosunku pracy oraz z innego tytułu niż stosunek pracy.

W koncepcji ryzyka postrzeganego jako prawo do zaprzestania pracy po osiągnięciu wieku emerytalnego sam wiek emerytalny nie wiązałby się ze ziszczeniem się ryzyka socjalnego, samo zaś ryzyko nie byłoby warunkiem nabycia prawa do emerytury. Stanowiłoby jednak przesłankę kształtowania prawa do emerytury, gdyż dopiero zaprzestanie aktywności zarobkowej pozwalałoby na wypłatę emerytury. Innymi słowy ubezpieczony — przez zaprzestanie wykonywania pracy po osiągnięciu wieku emerytalnego lub jej niepodejmowanie w trakcie pobierania emerytury - manifestowałby ziszczenie się ryzyka socjalnego. Ujęcie ryzyka jako prawa do zaprzestania pracy z zapewnieniem środków utrzymania pojawia się także w informacjach MOP (www.ilo.org) $)^{30}$.

W przeciwnym razie występująca dziś pełna możliwość łączenia dochodu z pracy zarobkowej z emeryturą deformuje socjalny aspekt ryzyka, gdyż gwarancja ubezpieczeniowa winna zapewniać łagodzenie skutków ryzyka, a nie służyć powiększeniu majątku ${ }^{31}$. Dlatego też należy uznać, że treścią ryzyka socjalnego w ubezpieczeniu emerytalnym winno być zaprzestanie pracy po osiągnięciu wieku emerytalnego. Zajście ryzyka następowałoby, gdyby emeryt zrezygnował z dalszej pracy zarobkowej na rzecz świadczenia ubezpieczeniowego.

Jednocześnie należy zauważyć, że przy takim postrzeganiu roli i treści ryzyka socjalnego w ubezpieczeniu emerytalnym trzeba rozważyć zagadnienie konieczności dorabiania do niskiej emerytury. W tym względzie należy podkreślić, że pożądane ze względu na problem starzenia się społeczeństw jest zachęcanie do jak najdłuższej aktywności zawodowej oraz zniechęcanie do wcześniejszego przechodzenia na emeryturę ${ }^{32}$. Dlatego też należy dążyć do kształtowania prawa do emerytury jako instytucji kompensującej z zachowaniem adekwatności systemów emerytalnych, to jest gwarantujących realizację celów społecznych, stratę w razie ziszczenia się ryzyka — rozumianego jako definitywne odjęcie z rynku pracy.

29 Por. W. Muszalski, op. cit., s. 224-225.

30 Występuje tam zwrot: right to affordable retirement - prawo do zaprzestania pracy z zapewnieniem środków utrzymania - D. Dzienisiuk, op. cit., s. 242.

31 K. Antonów, op. cit., s. 44-45.

32 H.H. Konkolewsky, op. cit., s. 15. 
Skorzystanie z tego prawa winna poprzedzać indywidualna ocena konieczności zaniechania aktywności zawodowej i zarobkowej z powodu starości i związanej $\mathrm{z}$ nią naturalnej utraty sił do pracy.

Nie jest natomiast zasadne promowanie rozwiązań łączenia pobierania emerytury z aktywnością zarobkową, uzasadnionych koniecznością dorabiania do niskiej emerytury, czyli w celu zabezpieczenia poziomu życia. Po pierwsze, nie każdy emeryt otrzymuje lub otrzyma względnie niską emeryturę (niska stopa zastąpienia), po drugie, w wielu przypadkach niska emerytura stanowi konsekwencję wyboru — niskiej składki.

Jeśli dąży się do adekwatnego standardu życia emerytów (brak ubóstwa i względnie stały poziom konsumpcji w cyklu życia), to należy zapobiegać niekorzystnym biografiom zawodowym oraz małemu udziałowi redystrybucji w formułach wymiaru emerytury. Chodzi więc o to, że oprócz wdrożonych już stabilizatorów finansowych (zapewnienie trwałego finansowania) należy wdrażać stabilizatory gwarantujące realizację celów społecznych. Dotyczy to przede wszystkim formuły wymiaru emerytury. Obecna formuła wedle zdefiniowanej składki zakłada, że gromadzony przez całe życie kapitał składkowy ulega podzieleniu przez oczekiwaną przeciętną statystycznie długość trwania życia w momencie przejścia na emeryturę. Problem niskich emerytur i związana z tym celowość dorabiania do emerytury został więc wygenerowany przez konkretne rozwiązania prawne - nie jest to kwestia jakiejś nieuchronności dziejowej, lecz wynik konkretnej decyzji politycznej. Formuła zdefiniowanej składki sprzyja osobom bardzo dobrze zarabiającym, gwarantując im relatywnie wysoką stopę zastąpienia, spłaszcza zaś świadczenia osób zarabiających nieco powyżej średniej, na poziomie średnim i znacznie poniżej średniej. Obecnie stopa zastąpienia w przypadku osób o średnich dochodach (średnie wynagrodzenia) - 52,8; o niskich dochodach ( 0,5 średniego wynagrodzenia) - 54; o wysokich dochodach (1,5 średniego wynagrodzenia) $-52,4^{33}$. Ponadto za 15-20 lat nowi emeryci mogą nie osiągnąć $40 \%$ stopy zastąpienia wymaganej przez konwencję nr 102 po 30 latach pracy (płacenia składek) z powodu braku w ich formule wymiaru emerytury kapitału początkowego. Tymczasem dla osób o niskich zarobkach stopy przeciwdziałające ubóstwu to $50-90 \%$ w zależności od kraju ${ }^{34}$.

Należy zatem zauważyć, że istotnym czynnikiem z punktu widzenia wysokości emerytury i jej wartości mierzonej stopą zastąpienia jest mechanizm waloryzacji składek. Stosowany sposób waloryzacji składek, wedle tempa wzrostu funduszu wynagrodzeń i tempa wzrostu PKB, będzie skutkował - jak się obecnie prognozuje - spadkiem stopy zastąpienia liczonej w stosunku do poziomu wynagrodzenia w chwili przejścia na emeryturę. Waloryzacja kapitału składkowego będzie bowiem niższa niż tempo wzrostu przeciętnych wynagrodzeń. W efekcie

33 Pension at a glance 2015. OECD and G20 Indicators, Paris 2015, s. 145.

${ }^{34}$ K. Hagemajer, op. cit., s. 25. 
niezależnie od zarobków ubezpieczonego w czasie jego aktywności zawodowej przy waloryzacji składek wskaźnikiem wzrostu funduszu wynagrodzeń (a nie na przykład wskaźnikiem wzrostu przeciętych płac) stopy zastąpienia dla młodszych roczników nie osiągną 40\% wymaganych przez konwencję nr 102 nawet po 45 latach ciągłego płacenia składek ${ }^{35}$. Konwencja zaś wymaga stopy zastąpienia na poziomie $40 \%$ dla osób o niższych zarobkach już po 30 latach płacenia składek. W polskim prawie emerytalnym mamy zatem silny mechanizm poprawiający równowagę finansową systemu na wypadek obniżenia liczby ubezpieczonych, brakuje zaś stabilizatorów gwarantujących realizację celów społecznych — adekwatnej emerytury, zarówno w chwili przejścia na emeryturę, jak i w całym okresie jej pobierania (szybki spadek wartości realnej emerytury — waloryzacja cenowa).

\title{
SOCIAL RISK IN PENSION INSURANCE. INTERNATIONAL AND NATIONAL LEGAL AND DOCTRINAL CONDITIONS
}

\author{
Summary
}

The article, based on the well-established view of the Polish doctrine that the fulfilment of social risk is a premise for providing social security benefits, calls into question the correctness of this thesis in relation to retirement. In addition, he asks the question whether, given the new circumstances that people face during their lives as a result of socioeconomic changes accompanying the transformation towards a post-industrial society - the premise for granting protection in the case of the right to a pension may be social risk. Further considerations focus on, among others on the issue of how possible "retirement (old age) risk" should be understood as social risk.

Keywords: social risk, retirement, social security law, social insurance, retirement age

\section{BIBLIOGRAFIA}

Antonów K., Prawo do emerytury, Warszawa 2004.

Börsch-Supan A., Demografia i czas aktywności zawodowej: co to jest „właściwy” wiek emerytalny?, „Ubezpieczenia Społeczne. Teoria i praktyka” 2018, nr 1.

Brosius-Gersdorf F., Kompensowanie w systemach emerytalnych okresów poza zatrudnieniem poświęconych opiece nad dziećmi i chorymi czlonkami rodziny, „Ubezpieczenia Społeczne. Teoria i praktyka" 2018, $\mathrm{nr} 1$.

Dzienisiuk D., Prawo pracy a prawo ubezpieczeń społecznych, Warszawa 2016.

Hagemajer K., Adekwatność zreformowanych systemów emerytalnych, „Ubezpieczenia Społeczne. Teoria i praktyka" 2018.

Jędrasik-Jankowska I., Pojęcia i konstrukcje prawne ubezpieczenia społecznego, Warszawa 2014. Jędrasik-Jankowska I., Ryzyka ubezpieczeniowe, [w:] Problemy prawne ubezpieczenia społecznego, red. B. Wagner, Kraków 1996.

Jończyk J., O ubezpieczeniu społecznym (wyktad), „Praca i Zabezpieczenie Społeczne” 2017, nr 9.

35 Ibidem, s. 38-39. 
Jończyk J., Prawo zabezpieczenia społecznego, Warszawa-Kraków 2006.

Jończyk J., ZUS jako instytucja ubezpieczeń społecznych, [w:] Problemy ubezpieczeń społecznych. W 70-lecie istnienia Zakładu Ubezpieczeń Społecznych, red. U. Jackowiak, A. Malaka, Wrocław 2004.

Konkolewsky H.H., Demografia, mobilność i migracje w Europie oraz wpływ tych zjawisk na stabilność systemów zabezpieczenia społecznego, [w:] Wyzwania XXI wieku a systemy emerytalne, Warszawa-Gdańsk 2015.

Lach D.E., Adekwatność systemu emerytalnego a ryzyko emerytalne — przyczynek do dyskusji, „Ubezpieczenia Społeczne. Teoria i praktyka” 2018, nr 1.

Lach D.E., O zabezpieczeniu na starość i ryzyku „starości” — raz jeszcze, „Praca i Zabezpieczenie Społeczne" 2014, nr 3.

Michalak J., Refleksje nad pojęciem ryzyka, „Ruch Prawniczy, Ekonomiczny i Socjologiczny” 2004, nr 1.

Michalski T., Ryzyko w działalności człowieka, [w:] Podstawy ubezpieczenia, t. 1. Mechanizm i funkcje, red. J. Monkiewicz, Warszawa 2000.

Muszalski W., Ubezpieczenie społeczne, Warszawa 2004.

Ślebzak K., Prawo do zabezpieczenia społecznego w Konstytucji RP. Zagadnienia podstawowe, Warszawa 2015.

Szumlicz T., Modele polityki społecznej. Monografie i Opracowania, Warszawa 1994.

Szumlicz T., Świadomość ryzyka społecznego jako podstawa wiedzy o systemie ubezpieczeń spotecznych, „Ubezpieczenia Społeczne. Teoria i praktyka” 2017, nr 1.

Uścińska G., Europejskie standardy zabezpieczenia społecznego a współczesne rozwiąania polskie, Warszawa 2005.

Uścińska G., Ryzyko jako przesłanka ochrony w systemie zabezpieczenia społecznego, „Polityka Społeczna" 2013, nr 11-12.

Wagner B., Przestanki prawa do emerytury w starym i nowym systemie, [w:] Ryzyko starości - problemy zabezpieczenia, red. U. Jackowiak, L. Abramowicz, Kraków 2007.

Wagner B., Wiek emerytalny jako zdarzenie prawa pracy, „Praca i Zabezpieczenie Społeczne” 2001, nr 3.

Zalewska H., Wybrane zagadnienia i dane statystyczne opisujace problem wieku emerytalnego, „Ubezpieczenia Społeczne. Teoria i praktyka” 2018, nr 1. 